\title{
Assessment of Problems and Prospects of Increasing the Level and Efficiency of Social Responsibility of Agricultural Enterprises
}

\author{
L. O. Marmul \\ Department of Economics \\ Pereiaslav-Khmelnytskyi Hryhorii \\ Skovoroda State Pedagogical \\ University \\ Pereiaslav-Khmelnytskyi, Ukraine \\ marmul61@ukr.net \\ http://orcid.org/0000-0002-5589-9338 \\ S. Yu. Kucherenko \\ Faculty of Finance and Humanities \\ Pereiaslav-Khmelnytskyi Hryhorii \\ Skovoroda State Pedagogical \\ University \\ Pereiaslav-Khmelnytskyi, Ukraine \\ ksvetau66@gmail.com \\ http://orcid.org/0000-0001-7560-1212
}

\author{
V. I. Aranchiy \\ Poltava State Agrarian Academy \\ Poltava, Ukraine \\ pdaa@pdaa.edu.ua \\ http://orcid.org/0000-0002-7391-2882
}

\author{
M. I. Navalna \\ Department of Document Science \\ Pereiaslav-Khmelnytskyi Hryhorii \\ Skovoroda State Pedagogical \\ University \\ Pereiaslav-Khmelnytskyi, Ukraine \\ mnavalna@gmail.com \\ http://orcid.org/0000-0002-5064-3122
}

Abstract - The subject of the study is the theoretical and practical aspects of the implementation and evaluation of social responsibility of agrarian enterprises. The purpose of the work is to identify, assess and analyze the level and effectiveness of social responsibility of agrarian enterprises and justify the directions, sources, means of increasing its volumes and distribution. Methodological bases of the article are general scientific, and special methods of scientific knowledge. Methods used: dialectical, monographic, historical, system and structural analysis and synthesis, problem and program-target approaches, statistical and economic, economic and mathematical, surveys. The article reveals features of social responsibility of domestic agrarian enterprises in terms of content, structure and dynamics. An assessment and analysis of its level, causes and risks of mass distribution have been made. Proved suggestions on its growth and efficiency increase. At the same time, we are talking not only about large, but also small and medium-sized agribusiness enterprises. For the first time, it was determined that large agribusiness should support small businesses in the context of social responsibility (through commodity lending, guaranteed sales of products, etc.) in order to form a middle class in rural areas and ensure social stability and progress. Conclusions and results of the article can be used in the educational-scientific process of the economic faculties of higher educational institutions. It is expedient to transfer them for practical use to agrarian enterprises, public organizations, rural communities. In the course of the research carried out, significant polarization was found in the effectiveness of development and social responsibility of large and small subjects of agrosphere management, which requires urgent solution to this problem. Indeed, small agricultural formations are understood not only as commodity producers, but they are the basis for the formation of the middle class in the countryside, promote employment and increase the well-being of the population. Therefore, large agribusiness should carry out social responsibility, supporting them, in particular, in the form of commodity lending, sale of finished goods, use of production capacities, development of cooperative and integration processes, and the introduction of innovations.

Keywords - social responsibility, agrarian enterprises, estimation, problems, level, efficiency, international experience, management, increasing, prospects.

\section{INTRODUCTION}

In recent years increasing attention is paid to the formation and popularization of social responsibility as one of the ways for improving society welfare. Thus, during the formation of the annual report "On Human Development", the UN increasingly focuses not only on material indicators of activity, but also on indicators of social and ecological direction (ecological and social sustainability). As for Ukraine, the level of social responsibility development is quite low, but in recent years there has been some revitalization of social responsibility, especially at the enterprise level. So, it is worth noting the social responsibility at such agrarian enterprises as "Kernel", "Nibulon", "Astarta-Kyiv", "Monsanto Ukraina", "Myronivskyi Hliboprodukt". This means that social responsibility takes place in Ukraine and in the long term it should be widely spread.

\section{ANALYSIS OF RECENT RESEARCH AND PUBLICATIONS.}

Many publications of domestic and foreign researchers are devoted to the main aspects of the development and popularization of social responsibility. Among them: O. Hrishnova, Y. Hryshyna, M. Ihnatenko, R. Kolyshko, F. Kotler, O. Lazarenko, O. Okhrimenko. As social responsibility is being studied and gaining popularity, there is a need to intensify the social and ecological factors of the development of business entities in Ukraine. Indeed, not only 
the standard of living of the rural population but also the society welfare in the country depends on the results of their management.

The purpose of the work is to identify, assess and analyze the level and effectiveness of implementing social responsibility of agrarian enterprises and justify the directions, sources, means of increasing its volumes and distribution.

\section{THE MAIN RESEARCH MATERIAL}

In the process of establishing social responsibility and managing its development in the subjects of management of the agrarian sphere of the economy it is necessary to take into account the specific features of agricultural production, the use of resources, especially land, population distribution and rural settlement systems, the spread of alternative activities in the countryside, and the level of organization of rural areas. In this regard, the preservation of natural resources and the provision of modern technological changes for the stable satisfaction of the needs of the population in quality food and food security is a strategic goal of long-term functioning of agroformations. This means that it is necessary to increase attention to the use of innovative environmental technologies to ensure economic efficiency and competitiveness of enterprises, increase the level of employment of workers and the living standards of the rural population in general, and improve the organization of rural areas on the basis of social responsibility.

The formation of social responsibility of agrosphere business entities is complicated by the fact that they are characterized by a significant difference in the forms of organization, the scale of activity, the magnitude of capitalization, profitability, the number of employees, the volume and directions of resources that can be spent on social responsibility without threats to financial and economic stability. On the other hand, the agrosphere environment is represented by a large number of intermediary organizations and processing enterprises, which, at the end of the reproductive chain, have certain preferences on the agro-food market and receive extra profits from their own activities, while not investing in socially responsible agro-sphere development programs in general.

Against the backdrop of insufficient state support, budgeting of agricultural production, rural territories, social protection of the rural population, in the agrarian sector of the economy there were significant socio-economic and industrial-environmental shifts, including negative. They relate to violations of regional and zonal systems of agricultural activity, soil depletion or loss of their fertility, the spread of destructive ecological processes in agrolandscapes due to excessive concentration of crops of energy-intensive crops and non-compliance with scientifically grounded crop rotation, loss of zoned vegetative originality and narrowing of the basic bases of seed production through the universal use of genetically modified (GM) - cultures, curling branches of livestock, production of germplasm fictitious food products.

In the social sphere there was a decrease in the infrastructure of rural areas, worsening of the living standards of the majority of rural residents due to the narrowing of the application of labor and unemployment in the countryside, migration processes, deterioration of social protection, medical care, vocational training. Proper development over the past 20 years did not receive rural green tourism as an alternative activity, leisure industry, housing and communal services [1, p. 100]. State rural development programs, rural green tourism, service cooperatives, animal husbandry, advisory services, departmental initiatives (eg, "Native Village") are not fully implemented or not implemented at all.

Business entities of the agrosphere are important systembudget elements of the national economy [2, p. 5]. Their share in GDP at the beginning of 2018 was $10,3 \%$. Agrobusinesses produced 15,0 billion dollars of gross value added. Agro-processing and food enterprises held more than $26,0 \%$ in the structure of the processing industry, surpassing metallurgical enterprises.

Consequently, food production facilities are producing 1,5 times more value added than the enterprises of other processing industries. The number of agrarian enterprises in 2017 exceeded 55,9 thousand units (including farms), processing enterprises $-9,5$ thousand units. The last ones had 418,7 thousand employees, products output totaled UAH 192,2 billion and more than UAH 21,5 billion of taxes received. (Table 1).

TABLE I. MAIN PRODUCTION AND ECONOMIC INDICATORS OF AGRARIAN AND PROCESSING ENTERPRISES OF UKRAINE, 2017

\begin{tabular}{|l|l|l|}
\hline \multicolumn{1}{|c|}{ Indicators } & \multicolumn{1}{|c|}{$\begin{array}{c}\text { Agrarian } \\
\text { enterprises }\end{array}$} & $\begin{array}{c}\text { Processing } \\
\text { enterprises }\end{array}$ \\
\hline Amount of enterprises, units & 56493 & 9573 \\
\hline Output, UAH million & 100536,2 & 192154,1 \\
\hline Number of employed, thousands of people & 595,0 & 418,7 \\
\hline Fixed investment, UAH million & 12106,0 & 8297,0 \\
\hline Fixed assets, UAH million & 101339,0 & 81778,0 \\
\hline Income profit (disbenefit), UAH million & 12750,5 & 2265,8 \\
\hline Rate of return, \% & 21,1 & 4,5 \\
\hline
\end{tabular}

The volume of employment in agrarian enterprises exceeded 500,0 thousand people. To this should be added more than 320,0 thousand household plots, which use agricultural machinery, as well as more than 3,8 million semi-natural household plots. In general, only $12,6 \%$ of the land was used for $78.3 \%$ of micro and small agroformations, and $21,7 \%$ of small and medium-sized ones accounted for $83,3 \%$ of the land. During the last decade (2007-2017), the growth rate of production in agricultural enterprises has exceeded $181,4 \%$, in processing $-45,1 \%$. This was due to the growth of labor productivity, first of all, in 5,3 times in agroformations, and it indicates the large scale, significance, and consequently, a significant social responsibility of the agrarian business entities.

By the end of 2017, the exports volume of domestic agroformations has reached 17,1 billion dollars or $26,0 \%$ in its total volume. However, the competitive potential of the agrosphere is not sufficiently used. Its business entities hold 2,0-3,0 times smaller share in GDP than in comparable to the resources of France, Argentina, Canada and Australia. Considerably fewer products are produced per 1 employed and per 100 hectares of lands than in the countries of the European Union.

This points to the problems of social responsibility and the existing capacity for solving them. In addition, there are 
$16,8 \%$ of rural households below the poverty line, in $48,8 \%$ of them the total costs do not exceed the subsistence level. The village is experiencing a demographic crisis, declining in population to 2,0 million people over the past 10 years. Among the villagers aged 16-59, 2,9 million people, or every third, did not work or study. The number of employed in agrarian enterprises continues to decrease.

There are the world's largest food corporations, companies with mixed capital in the country's food production. They make significant investments; initiate processes of concentration and monospecialization of production; capitalization and corporatization, capital outflow [3, p. 142]. They demonstrate examples of social responsibility towards their personnel, consumers, investors and shareholders, with a high level of rate and income. Small and medium-sized agrarian enterprises often show negative rate, and thus have insufficient financial resources for social responsibility. In general, about $1,5-2,5 \%$ of agricultural income goes to charity. Its main directions are responsibility for basic production, payment of taxes, concern for the personnel, ecologization of activities, external charity [4, p. 27].

They are implemented in forms of optimization of business processes and the introduction of innovations in basic production, cost reductions, expand the range, improve the quality of food products and their availability to consumers; motivation and innovative staff training; participation in environmental programs and projects; participation in socially significant events, patronage, volunteering, fundraising, etc. [5, p. 135]. At the same time, the mechanisms of state support for priority innovation and investment projects, infrastructure support for integration processes of agrosphere business entities, standardization and certification of food products for quality and environmental safety are insufficiently used.

It is determined that a significant stimulus and a significant result of the social responsibility of agrosphere business entities are the improvement of their business reputation, the image of reliable and decent partners, investment attractiveness, and the growth of competitive advantages in the agrarian market in general [6, p. 136]. However, among researchers, and in business practice, there is no single approach to their achievement on the basis of social responsibility. To this end, we have developed a system of expectations and indicators for assessing changes in the reputation of agrarian enterprises by key stakeholders - shareholders, investors, employees, consumers, partners, government bodies, public and other organizations, and the mass media (Figure 1).

It was established that for $67,0 \%$ of domestic business entities the formation of social responsibility is not relevant due to the lack of necessary funds. $10,0 \%$ of them consider it as the state's function, $59,8 \%$ carry it mainly at the domestic level. Almost $30,0 \%$ of enterprises have codes of business conduct and market responsibility, but only $17.0 \%$ of them have allocated independent budgets or special budget articles for social programs, projects or activities. Consequently, the models of social responsibility of domestic agrosphere businesses entities are in the stages of formation [7, p. 114].

In Ukraine, in recent decades, the formation of market mechanisms and institutions of management in the environment of business entities agrosphere is accompanied by the development of social responsibility of business mainly mixed type or model. It comprises the involvement of state and social institutions in the process of harmonizing public interests provided that enterprises, corporations and trade unions maintain autonomy, that is, the principle of voluntary social activity is maintained. Social responsibility of business in Ukraine develops rather spontaneously, without adequate institutional support of permanent advisory intermediary organizations that could collect or develop ideas for JIs (social responsibility) and provide relevant services to economic entities in the implementation of their social activities and programs [8, p. 153].

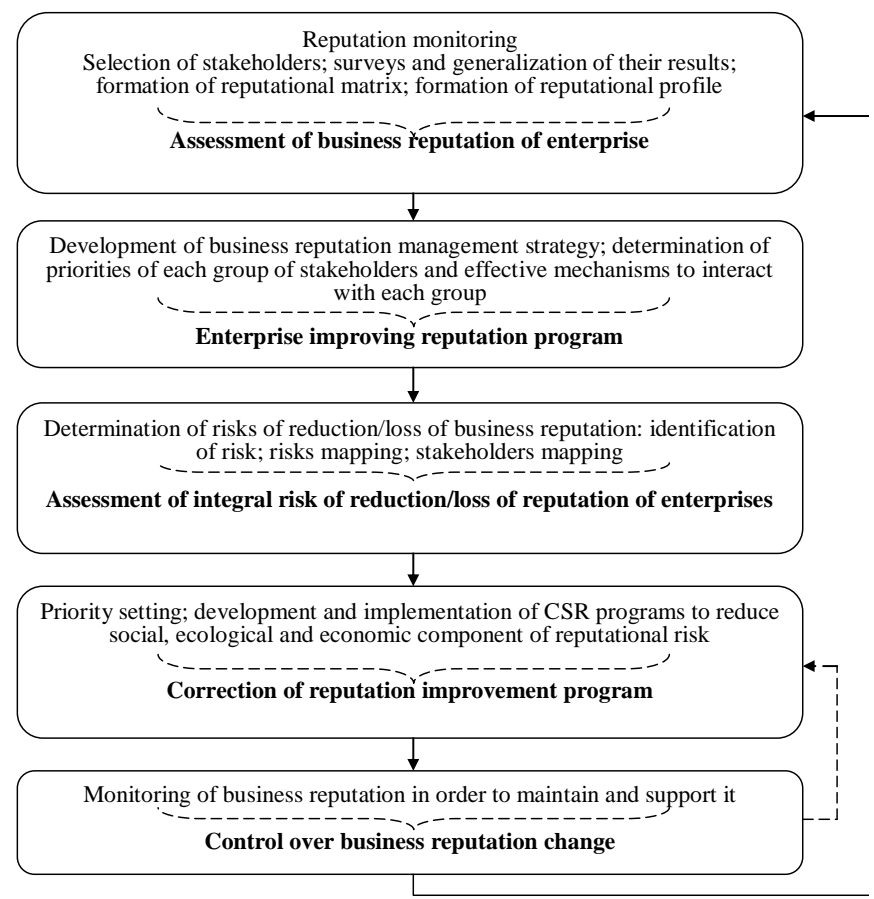

Fig. 1. Processes of managing the business reputation of agrosphere business entities in the context of social responsibility.

Consequently, there is no reason to state the current domestic model of social responsibility, but one can speak about the existence of specific problems and development trends inherent in this area of activity for Ukraine and other countries of the post-Soviet space. Traditionally, the vectors for further development of JI are defined by state and regional institutes. In the past, the state itself as a strategically oriented entity of management and livelihoods exercised the functions of social protection of the population with the involvement of enterprises quite effectively.

In modern conditions, state institutions have no less effective levers and regulators in relation to the involvement of businesses at the level of agroformation to socially responsible activities. It is about using fiscal and tax incentives to promote corporate social responsibility; active propagation of values and standards of social economy, ecologization of activity, introduction of innovations, attraction of investments. State support is deserved by local, regional, national and international initiatives related to social responsibility, the development of public-private partnerships in this area, sustainable environmental development. 
An important place in the context of development trends and problems of the implementation of the national JI model belongs to the development of requirements for the disclosure of information, the introduction of standards for the formation and verification of social reporting of economic entities. The organization of monitoring and development of mechanisms for monitoring the implementation of social responsibility are necessary. This will contribute to strengthening national and international ratings, image and reputation of individual agribusinesses and corporations as well as of the state as a whole.

Among the problems that hinder the spread of social responsibility, apart from those mentioned, are the lack of information about it, the non-binding nature of non-financial reports, their poor quality [9, p. 298]. Thus, out of 61 large Ukrainian corporations that have joined the Global Compact on corporate social responsibility, 46 have not submitted reports on it. In our opinion, the main obstacle to the implementation of social responsibility is not the lack of funds in agricultural enterprises, but stimulus and understanding of its importance, recognition of its debts to society, insufficient control by trade unions, public organizations, and the general population at large.

State institutions do not control enough the implementation and enforcement of standards on social responsibility, ethical consumption of resources in general. Trends in its implementation are maintained based on the internal beliefs of management and owners. There are practically no differences in the content of social responsibility between domestic and foreign enterprises, but in domestic practice it is characterized by a focus on solving internal problems, and then external environmental and social actions [10, p. 128]. There is a problem of insufficient consideration of interests of stakeholders in social responsibility.

\section{CONCLUSIONS}

In the course of the research carried out, significant polarization was found in the effectiveness of development and social responsibility of large and small subjects of agrosphere management, which requires urgent solution to this problem. Indeed, small agricultural formations are understood not only as commodity producers, but they are the basis for the formation of the middle class in the countryside, promote employment and increase the wellbeing of the population. Therefore, large agrobusiness should carry out social responsibility, supporting them, in particular, in the form of commodity lending, sale of finished goods, use of production capacities, development of cooperative and integration processes, and the introduction of innovations.

\section{REFERENCES}

[1] I.V. Goncharenko, "Socio-economic problems of the modern period of Ukraine. Priorities and mechanisms of social and economic development of rural territories", Yearbook of scientific works. Lviv: Institute for Regional Studies of the National Academy of Sciences of Ukraine, vol. 6 (104), pp. 95-103, 2013.

[2] O. Hrishnova, "Social responsibility of business: the essence, significance, strategic directions of development in Ukraine", Ukrayina: aspekty pratsi, vol. 7, pp. 3-8, 2010.

[3] F. Kotler, and N. Li, Corporate social responsibility: how to do as much good as possible for your company and society. Kyiv. Vyd-vo O. Kapusty; Ahentsiya «Standart», 2005.

[4] Yu. M. Petrushenko, and O. V. Dudkin, "Formation of the Institute of Positive Social Responsibility", Naukovi pratsi Donets'koho natsional'noho tekhnichnoho universytetu. Seriya: ekonomichna, vol. $37-3$, pp. $25-31,2009$.

[5] O. Okhrimenko, and T. Ivanova, Social Responsibility. Kyiv. Natsional'nyy tekhnichnyy universytet Ukrayiny «Kyyivs'kyy politekhnichnyy instytut», 2015.

[6] L. O. Marmul, and I. A. Romaniuk, Labor market and rural population employment: the theory and practice of regulation. Kherson. Aylant, 2015.

[7] V. M. Shapoval, Social responsibility of business in the structure of economic management. Dnipropetrovs'k. DVNZ "NHU”, 2011.

[8] O. I. Shibko, "Growth of social responsibility as an objective pattern of civilization advancement”, Skhid, vol. 5(119), pp. 150-153, 2012.

[9] M. M. Ignatenko, Strategies and mechanisms for managing the development of social responsibility of economic entities of the agrarian sector of the economy. Kherson. Aylant, 2015.

[10] M. M. Ihnatenko, and N. P. Novak, "Development of regional programs for the development of agrarian enterprises with organic production on the basis of the European and international experience", Baltic Journal of Economic Studies, vol. 4, pp. 126-133, 2018 . 